\title{
Exploring the Inter-relationships amongst the Various Enablers of Measuring Customer Experience towards Organic Food Products in India using ISM Methodology
}

\author{
Bhoomica Aggarwal \\ HCL Technologies Private Limited \\ Noida, India
}

\author{
Remica Aggarwal \\ School of Business, University of \\ Petroleum \& Energy Studies, \\ Dehradun, India
}

\author{
Ratna Banerjee \\ School of Business, University of \\ Petroleum \& Energy Studies, \\ Dehradun, India
}

\begin{abstract}
Organic food products are recently becoming quite popular and the credit goes to the changing consumer preferences and an inclination for trying innovative, healthier and better food options which are more environment friendly as compared to traditional food products. Present research work explore the various enablers or factors which influence the customer attitude to purchase the organic food products. After recognizing the various criteria, the inter-relationships amongst these criteria have been studied with the help of Interpretive Structural Modeling (ISM) methodology.
\end{abstract}

\section{Keywords}

Interpretive Structural Modeling Methodology (ISM); Organic food products; Sustainable products

\section{INTRODUCTION}

Today's customers are more aware of the benefits and goodness of sustainable food products. It is not only the customers but also the new government policies for new product development which stresses on developing sustainable food products which are environment friendly. These products are cultivated using bio-composites or fertilizers. Benefits of organic foods have been overwhelmingly realized in India as well .

Consumer behavior and attitude towards the purchase of sustainable food products is often governed by various factors such as their beliefs, perceptions and purchasing behavior . Present research aims to explore the various enablers for judging the consumer behavior and attitudes towards organic food products. It relates to the factors such as the consumption patterns along with the consumers' understanding and points of view towards organic food and their education levels as well as their demographic, purchasing pattern and socioeconomic profiles. After identifying the various factors of measuring consumer attitudes and behavior towards organic food products, it measures the inter-relationships amongst those factors using interpretive structural modeling technique.

The paper is arranged as follows: Section 2 deals with the literature review. Section 3 describes the case problem and identifies various factors. Section 4 describes the ISM methodology and its applications. Section 5 prioritize the various factors using ISM methodology. Section 6 presents the managerial implications of using the methodology and extensions whereas section 7 presents conclusions and directions for future research.

\section{LITERATURE REVIEW AND IDENTIFICATION OF FACTORS}

The factors were identified using literature survey and google search as well as experts opinion. Keywords such as 'organic food products', 'consumer perception and organic food products ', 'consumer attitudes and organic food products' 'sustainable products', 'consumer buying behavior and sustainable food products' etc. have been searched over internet to get relevant abstracts of research papers or full research papers based on the topic. In order to broaden the timeline of the survey, the same and/or similar keywords has been utilized for performing a further search through the webbased GoogleScholarTM tool, Mendeley software and Research Gate engine. Thus, the resulting list of reference papers attempts to covers the last fifteen years period. Among the many determinants of sustainable product choices, consumer attitude and motivation to purchase as well as consumer belief and perception towards the purchase of organic food product is found to be as one of the most effective factors [1-12]. Similarly, [2],[13], [14], [15] consider consumer willingness to pay and consumer intention to buy organic food products as the main criteria which are influence by health factors, hygiene etc. [3] mentioned the purchasing behavior of consumers often gets influence by gender, age, occupation, health factors, price and quality. Attitude usually gets influenced by beliefs, perceptions and purchasing behavior of the consumer towards organic food products and hence they form the major criteria. These criteria are further influenced by various sub criteria which are explained as follows :

\subsection{Authentication and organic labels} (Au)

Usually the organic products are labelled by fssai . Only agricultural products that achieve organic certification can use the label 'organic'. Such products include foods and beverages such as cheese, chocolate, cookies, juices, meats, milk, pasta, poultry, prepared sauces, soups, wines and alcoholic beverages, etc. Awareness of organic labels can increase the probability that consumers would be willing to pay a premium for organic food products [16]. In contrast, consumers experiencing more difficulty in identifying organic foods labels will likely show a drop in their intention to purchase organic foods [7]. Organic labelling was considered important factor while making a purchase and various variables taken under study were age, income, number of adults, family size , marriage and employment as the major variables under study ([17],[18]) . 


\subsection{Nutrition \& health (NH)}

Wholesomeness, absence of chemicals, environment friendliness and a better taste have been cited as primary reasons to justify the purchase of organic foods [19]. In order to describe the emerging consumer groups, factors such as nutritional values, naturalness or health values of food products, as well as socio demographic attributes were used. $[20,21,22,23]$ consider health related determinants .

\subsection{Quality of food product $(\mathrm{Qu})$}

Perceive quality is another factor to be vital on consumer's purchase behavior. As per [8] shoppers would like to see more variety from where they can select products to purchase. The two quality aspects of food product viz. the taste and visual attractiveness are factors related to the frequency of buying organic fruits and vegetables [13].

\subsection{Past experience (PE)}

A few researchers [24,25] have found that past experience is an important factor influencing consumer attitude to purchase products or services. In a study at South Korea, [24] reported that past experience have a positively significant influence on consumers' purchase intention of organic food.

\subsection{Personal values (PV)}

According to [26], values can be categorized in to conservatism, self- enhancement, self- transcendence and openness to change. Ethical concern on animal welfare was an important influencing factor in decision to purchase organic food [26]. Lifestyle is also the most important factors for the motives to purchase organic food [27].

\subsection{Physical image / packaging and presentation $(\mathbf{P I})$}

Organic food is best served when the acidic, basic and other properties are maintained till it is consumed by end customer. Organic food producers use an array of visual and verbal rhetorical strategies to make ethical, logical, and pathetic appeals to persuade the consumer to purchase their products. [28] argued that the physical image and presentation of organic produce are good enough to hasten consumption and social acceptance. Usually jute and cotton bags, wooden packs, gunny bags or bio plastics are used for packaging. Aluminium is the most widely used packaging material. Flexible packaging incorporates the good properties of each material (paper/plastics/aluminium) to create a tailor made packaging solutions for a product.

\subsection{Demographic factors (DF)}

[29] opined that gender has a profound effect on organic buying behavior, and contrary to the findings of [13], they identified men in U.K. spent more money on organic products than women without offering an explanation. Further they revealed that age and income also influences the consumer behavior. Additionally, their results confirmed that the younger generation spent more money for organic food than did older people. The results of [13] found that with increasing family size, willingness to pay for organic products will increase.

\subsection{Price / price sensitivity $(\mathrm{Pr})$}

The price premium (generally 50-70 \% more than conventional food) is a determining factor. For a lot of shoppers $[30,31,11]$ consider pricing as the main criteria and consider variables such as employment and income status .

\subsection{Education and awareness (EA)}

As per [14] viewpoint, consumers with a higher education level are more concerned with ethical issues and other sensitive information related to the organic production system

- Further, the study by [32] investigates the association between consumers' subjective knowledge, objective knowledge and general attitudes towards organic food and organic vegetables consumption.

\subsection{Environmental concern (EC)}

According to [27], the increasing awareness on environmental degradation has changed consumer attitude to purchase more environmental-friendly and organic product. Ethical concern on animal welfare was an important influencing factor in decision to purchase organic food [5].

\section{ISM METHODOLOGY}

Suggested by [33], the technique has been used widely to develop a map of the relationships between the many elements in the form of a hierarchy graph. Group's judgement decides whether and how the items are related.

ISM works with the following steps:

[1] Identification of elements, which are relevant to the decision maker's problems and issues.

[2] Establishing the contextual relationship between elements and with respect to which pairs of elements will be examine.

[3] A structural self-interaction matrix (SSIM) may be developed between two variables i.e. $i$ and $j$. It establishes the "Lead to" relationship between criteria. Four symbols viz. $V, A, X \& O$ are used for establishing the relationships.

[4] SSIM may be further used to develop an initial reachability matrix which has all values in binary form. Rule of transitivity is usually checked at this stage. After removing the transitivity, final reachability matrix will form.

[5] Afterwards, the reachability set and antecedent set for each criterion and for each element can be obtained from the final reachability matrix .

[6] After that a level partition matrix can be obtained based on establishing the precedence relationships and arranging the elements in a topological order.

[7] A Mic-Mac analysis can be performed which categorize the variables as per the driving and dependence power in to autonomous, dependent, driver and linkage category.

[8] Finally a diagraph can be obtained.

\section{NUMERICAL ILLUSTRATION}

In this section, ISM model is developed for analyzing the interrelationships between various factors affecting consumers perception, beliefs and purchase behavior of consumers which in turn affects their attitude towards purchase of organic food products in India. Around 10 variables are considered important. They are authentication or organic labelling $(\mathrm{Au})$; nutrition \& health $(\mathrm{NH})$, quality $(\mathrm{Qu})$; past experience (PE), personal values (PV); physical image (PI) ; demographic factors (DF) ; price/price sensitivity $(\mathrm{Pr})$; education and awareness (EA) and environmental concern (EC). A detail about these variables has also been presented in [34]. 


\subsection{Construction of Structural Self- Interaction Matrix (SSIM)}

This matrix gives the pair-wise relationship between two variables i.e. $i$ and $j$ based on VAXO.

Table 2. Structural self - interaction matrix

\begin{tabular}{|c|c|c|c|c|c|c|c|c|c|c|}
\hline $\begin{array}{c}\text { Barrie } \\
\text { rs }\end{array}$ & 1 & 2 & 3 & 4 & 5 & 6 & 7 & 8 & 9 & 10 \\
\hline & $\begin{array}{l}\mathrm{A} \\
\mathrm{u}\end{array}$ & $\begin{array}{l}\mathrm{N} \\
\mathrm{H}\end{array}$ & $\begin{array}{l}\mathrm{Q} \\
\mathrm{u}\end{array}$ & $\begin{array}{l}P \\
E\end{array}$ & V & $\begin{array}{l}\mathrm{P} \\
\mathrm{I}\end{array}$ & $\begin{array}{l}D \\
F\end{array}$ & $\begin{array}{l}\mathrm{P} \\
\mathrm{r}\end{array}$ & $\begin{array}{l}\text { E } \\
A\end{array}$ & $\begin{array}{l}\mathrm{E} \\
\mathrm{C}\end{array}$ \\
\hline $\mathrm{Au}$ & & V & V & A & V & A & A & V & A & $\mathrm{A}$ \\
\hline $\mathrm{NH}$ & & & A & A & A & A & A & V & A & A \\
\hline $\mathrm{Qu}$ & & & & A & A & A & A & V & $\mathrm{O}$ & A \\
\hline PE & & & & & V & A & A & A & A & V \\
\hline PV & & & & & & A & $X$ & V & A & V \\
\hline PI & & & & & & & A & $\mathrm{V}$ & A & $\mathrm{V}$ \\
\hline DF & & & & & & & & $\mathrm{V}$ & $\mathrm{O}$ & $\mathrm{V}$ \\
\hline $\operatorname{Pr}$ & & & & & & & & & $\mathrm{O}$ & $\mathrm{O}$ \\
\hline EA & & & & & & & & & & V \\
\hline $\mathrm{EC}$ & & & & & & & & & & \\
\hline
\end{tabular}

\subsection{Construction of Initial reachability}

\section{matrix}

The SSIM has been converted in to a binary matrix called the initial reachability matrix by substituting $\mathrm{V}, \mathrm{A}, \mathrm{X}, \mathrm{O}$ by 1 or 0 as per the case. After incorporating the transitivity, the final reachability matrix is shown below in the table III.

Table 3. Initial reachability Matrix

\begin{tabular}{|c|c|c|c|c|c|c|c|c|c|c|}
\hline Barriers & 1 & 2 & 3 & 4 & 5 & 6 & 7 & 8 & 9 & 10 \\
\hline & LK & $\mathrm{L}$ & US & HI & $\mathrm{T}$ & II & $\mathrm{L}$ & $\mathrm{L}$ & $\mathrm{R}$ & W \\
\hline & A & $\mathrm{S}$ & G & $\mathrm{C}$ & LI & $\mathrm{P}$ & D & SP & $\mathrm{C}$ & GE \\
\hline LKA & 1 & 1 & 0 & 1 & 1 & 1 & 1 & 1 & 1 & 1 \\
\hline LS & 0 & 1 & 0 & 0 & 0 & 1 & 1 & 1 & 1 & 1 \\
\hline USG & 1 & 1 & 1 & 1 & 1 & 1 & 1 & 1 & 1 & 1 \\
\hline HIC & 0 & 1 & 0 & 0 & 0 & 0 & 0 & 0 & 0 & 0 \\
\hline TLI & 0 & 1 & 0 & 0 & 1 & 1 & 1 & 1 & 1 & 0 \\
\hline IIP & 0 & 0 & 0 & 0 & 1 & 0 & 1 & 1 & 1 & 0 \\
\hline LD & 0 & 0 & 0 & 0 & 1 & 0 & 1 & 1 & 1 & 0 \\
\hline LSP & 0 & 0 & 0 & 0 & 1 & 0 & 0 & 1 & 1 & 0 \\
\hline $\mathrm{RC}$ & 0 & 0 & 0 & 0 & 1 & 0 & 0 & 0 & 1 & 0 \\
\hline WGE & 0 & 0 & 1 & 0 & 1 & 1 & 1 & 1 & 1 & 1 \\
\hline
\end{tabular}

\subsection{Construction of final reachability}

\section{matrix}

After removing the transitivity, final reachability matrix is obtained along with the driving power as well as dependence power. Based on driving power and dependencies, these factors may be classified in to four groups of autonomous, dependent, linkage and independent (driver) factors.

Table 4. Final reachability matrix

\begin{tabular}{|c|c|c|c|c|c|c|c|c|c|c|c|c|}
\hline & Barriers & 1 & 2 & 3 & 4 & 5 & 6 & 7 & 8 & 9 & 10 & $\begin{array}{c}\text { D. } \\
\text { P }\end{array}$ \\
\hline & & L & L & U & I & T & I & L & L & R & W & \\
& & K & S & S & C & L & I & D & S & C & G & \\
A & & G & & I & P & & P & & E & \\
\hline 1. & LKA & 1 & 1 & 0 & 1 & 1 & 1 & 1 & 1 & 1 & 1 & 9 \\
\hline 2. & LS & 0 & 1 & 0 & 0 & 1 & 1 & 1 & 1 & 1 & 1 & 7 \\
\hline 3. & USG & 1 & 1 & 1 & 1 & 1 & 1 & 1 & 1 & 1 & 1 & 10 \\
\hline 4. & IC & 0 & 1 & 0 & 1 & 0 & 1 & 1 & 1 & 1 & 1 & 7 \\
\hline 5. & TLI & 0 & 1 & 0 & 0 & 1 & 1 & 1 & 1 & 1 & 0 & 6 \\
\hline 6. & IIP & 0 & 0 & 0 & 0 & 1 & 1 & 1 & 1 & 1 & 0 & 5 \\
\hline 7. & LD & 0 & 0 & 0 & 0 & 1 & 0 & 1 & 1 & 1 & 0 & 4 \\
\hline 8. & LSP & 0 & 0 & 0 & 0 & 1 & 0 & 0 & 1 & 1 & 0 & 3 \\
\hline 9. & RC & 0 & 0 & 0 & 0 & 1 & 0 & 0 & 0 & 1 & 0 & 2 \\
\hline 10 & WGE & 0 & 1 & 1 & 0 & 1 & 1 & 1 & 1 & 1 & 1 & 8 \\
\hline & De .P. & 2 & 6 & 2 & 3 & 9 & 7 & 8 & 9 & 10 & 5 & \\
& & & & & & & & & & & & \\
\hline & & & & & & & & & & & & \\
\hline
\end{tabular}

\subsection{Level Partition}

From the final reachability matrix, reachability and final antecedent set for each factor are found. The element for which the reachability and intersection sets are same are the top-level element in the ISM hierarchy. After the identification of top level element, it is separated out from the other elements and the process continues for next level of elements. Reachability set, antecedent set, intersection set along with different level for elements have been shown below in table 5 to table 11 .

Table 5. Iteration I

\begin{tabular}{|c|c|c|c|c|}
\hline S.No. & $\begin{array}{c}\text { Reachabili } \\
\text { ty set }\end{array}$ & $\begin{array}{l}\text { Antecedent } \\
\text { set }\end{array}$ & $\begin{array}{c}\text { Intersectio } \\
\text { n set }\end{array}$ & $\begin{array}{c}\text { Iterati } \\
\text { on/ } \\
\text { Levels }\end{array}$ \\
\hline 1. & 8 & $\begin{array}{c}1,2,3,4,5,6,7,8 \\
9,10\end{array}$ & 8 & I \\
\hline 2. & 2,8 & $\begin{array}{c}1,2,3,4,5,6,7,9 \\
10\end{array}$ & 2 & \\
\hline 3. & 2,3 & $\begin{array}{c}1,3,4,5,6,7,9 \\
10\end{array}$ & 3 & \\
\hline 4. & 3,10 & $1,4,5,6,7,9,10$ & 10 & \\
\hline 5. & 7,8 & $1,4,5,7,9$ & 7 & \\
\hline 6. & 3,7 & $1,4,5,6,7,9,10$ & 7 & \\
\hline 7. & $7,8,10$ & $1,4,5,7,9$ & 7 & \\
\hline 8. & 6,8 & $6,7,9$ & 6 & \\
\hline 9. & $1,2,3$ & $1,4,6,7,9$ & 1 & \\
\hline 10. & $4,7,8$ & $4,5,7,9$ & 4,7 & \\
\hline
\end{tabular}




\begin{tabular}{|c|c|c|c|}
\hline 11. & 5,8 & $1,4,5,6,7,9$ & 5 \\
\hline 12. & $\begin{array}{c}1,2,3,4,5,6 \\
7,8,9,10\end{array}$ & 9 & 9 \\
\hline 13. & $\begin{array}{c}2,3,4,5,7,8 \\
10\end{array}$ & 4 & 4 \\
\hline 14. & $\begin{array}{c}1,2,3,4,5,6 \\
8,10\end{array}$ & 6 & 6 \\
\hline 15. & $\begin{array}{c}1,2,3,4,5,6 \\
8,10\end{array}$ & 6,7 & 6 \\
\hline 16. & $2,3,8,10$ & 9,10 & 10 \\
\hline 17. & $\begin{array}{c}1,2,3,4,5,6 \\
7,8,10\end{array}$ & 9,7 & 7 \\
\hline
\end{tabular}

Table 6. Iteration II

\begin{tabular}{|c|c|c|c|c|}
\hline $\begin{array}{l}\text { S.N } \\
\text { o. }\end{array}$ & $\begin{array}{c}\text { Reachabili } \\
\text { ty set }\end{array}$ & Antecedent set & $\begin{array}{c}\text { Interse } \\
\text { ction } \\
\text { set }\end{array}$ & $\begin{array}{c}\text { Iteratio } \\
\mathbf{n} / \\
\text { Levels }\end{array}$ \\
\hline 2. & 2 & $1,2,3,4,5,6,7,9,10$ & 2 & \multirow{16}{*}{ II } \\
\hline 3. & 2,3 & $1,3,4,5,6,7,9,10$ & 3 & \\
\hline 4. & 3,10 & $1,4,5,6,7,9,10$ & 10 & \\
\hline 5. & 7 & $1,4,5,7,9$ & 7 & \\
\hline 6. & 3,7 & $1,4,5,6,7,9,10$ & 7 & \\
\hline 7. & 7,10 & $1,4,5,7,9$ & 7 & \\
\hline 8. & 6 & $6,7,9$ & 6 & \\
\hline 9. & $1,2,3$ & $1,4,6,7,9$ & 1 & \\
\hline 10. & 4,7 & $4,5,7,9$ & 4,7 & \\
\hline 11. & 5,8 & $1,4,5,6,7,9$ & 5 & \\
\hline 12. & $\begin{array}{c}1,2,3,4,5,6 \\
7,9,10\end{array}$ & 9 & 9 & \\
\hline 13. & $\begin{array}{c}2,3,4,5,7,1 \\
0\end{array}$ & 4 & 4 & \\
\hline 14. & $\begin{array}{c}1,2,3,4,5,6 \\
10\end{array}$ & 6 & 6 & \\
\hline 15. & $\begin{array}{c}1,2,3,4,5,6 \\
10\end{array}$ & 6,7 & 6 & \\
\hline 16. & $2,3,10$ & 9,10 & 10 & \\
\hline 17. & $\begin{array}{c}1,2,3,4,5,6 \\
7,10\end{array}$ & 9,7 & 7 & \\
\hline
\end{tabular}

Table 7. iteration III

\begin{tabular}{|l|l|l|l|l|}
\hline $\begin{array}{l}\text { S.N } \\
\text { o. }\end{array}$ & $\begin{array}{l}\text { Reachabilit } \\
\text { y set }\end{array}$ & $\begin{array}{l}\text { Antecedent } \\
\text { set }\end{array}$ & $\begin{array}{l}\text { Intersecti } \\
\text { on set }\end{array}$ & $\begin{array}{l}\text { Iteratio } \\
\text { n/ } / \\
\text { Levels }\end{array}$ \\
\cline { 1 - 3 } 3. & $\mathbf{3}$ & $\begin{array}{l}1,3,4,5,6,7,9, \\
10\end{array}$ & $\mathbf{3}$ & \\
\cline { 1 - 3 } & 3,10 & $\begin{array}{l}1,4,5,6,7,9,1 \\
0\end{array}$ & 10 & III \\
\hline
\end{tabular}

\begin{tabular}{|c|l|l|l|}
\hline 5. & 7 & $1,4,5,7,9$ & 7 \\
\hline 6. & 3,7 & $\begin{array}{l}1,4,5,6,7,9,1 \\
0\end{array}$ & 7 \\
\hline 7. & 7,10 & $1,4,5,7,9$ & 7 \\
\hline 8. & 6 & $6,7,9$ & 6 \\
\hline 9. & 1,3 & $1,4,6,7,9$ & 1 \\
\hline 10. & 4,7 & $4,5,7,9$ & 4,7 \\
\hline 11. & 5,8 & $1,4,5,6,7,9$ & 5 \\
\hline 12. & $\begin{array}{l}1,3,4,5,6,7,9, \\
10\end{array}$ & 9 & 9 \\
\hline 13. & $3,4,5,7,10$ & 4 & 4 \\
\hline 14. & $1,3,4,5,6,10$ & 6 & 6 \\
\hline 15. & $1,3,4,5,6,10$ & 6,7 & 6 \\
\hline 16. & 3,10 & 9,10 & 10 \\
\hline 17. & $\begin{array}{l}1,3,4,5,6,7,1 \\
\end{array}$ & 9,7 & 7 \\
\hline
\end{tabular}

Table 8. Iteration IV

\begin{tabular}{|c|c|c|c|c|}
\hline S.No. & $\begin{array}{c}\text { Reachabili } \\
\text { ty set }\end{array}$ & $\begin{array}{c}\text { Anteceden } \\
\text { t set }\end{array}$ & $\begin{array}{c}\text { Intersectio } \\
\text { n set }\end{array}$ & $\begin{array}{c}\text { Iteration } \\
\text { / Levels }\end{array}$ \\
\hline 4. & 10 & $\begin{array}{c}1,4,5,6,7,9 \\
10\end{array}$ & 10 & \multirow{13}{*}{ IV } \\
\hline 5. & 7 & $1,4,5,7,9$ & 7 & \\
\hline 6. & 7 & $\begin{array}{c}1,4,5,6,7,9 \\
10\end{array}$ & 7 & \\
\hline 7. & 7,10 & $1,4,5,7,9$ & 7 & \\
\hline 8. & 6 & $6,7,9$ & 6 & \\
\hline 9. & 1 & $1,4,6,7,9$ & 1 & \\
\hline 10. & 4,7 & $4,5,7,9$ & 4,7 & \\
\hline 11. & 5 & $1,4,5,6,7,9$ & 5 & \\
\hline 12. & $\begin{array}{c}1,4,5,6,7,9, \\
10\end{array}$ & 9 & 9 & \\
\hline 13. & $4,5,7,10$ & 4 & 4 & \\
\hline 14. & $1,4,5,6,10$ & 6 & 6 & \\
\hline 15. & $1,4,5,6,10$ & 6,7 & 6 & \\
\hline 16. & 10 & 9,10 & 10 & \\
\hline
\end{tabular}

Table 9. Iteration $\mathrm{V}$

\begin{tabular}{|c|c|c|c|c|}
\hline $\begin{array}{c}\text { S.No } \\
\text {. }\end{array}$ & $\begin{array}{l}\text { Reachabilit } \\
\text { y set }\end{array}$ & $\begin{array}{c}\text { Anteceden } \\
\text { t set }\end{array}$ & $\begin{array}{c}\text { Intersectio } \\
\text { n set }\end{array}$ & $\begin{array}{c}\text { Iteration } \\
\text { / Levels }\end{array}$ \\
\hline 8. & 6 & 6,9 & 6 & \multirow{8}{*}{ V } \\
\hline 9. & 1 & $1,4,6,9$ & 1 & \\
\hline 10. & 4 & $4,5,9$ & 4 & \\
\hline 11. & 5 & $1,4,5,6,9$ & 5 & \\
\hline 12. & $1,4,5,6,9$ & 9 & 9 & \\
\hline 13. & 4,5 & 4 & 4 & \\
\hline 14. & $1,4,5,6$ & 6 & 6 & \\
\hline 15. & $1,4,5,6$ & 6 & 6 & \\
\hline
\end{tabular}


Table 10. Iteration VI

\begin{tabular}{|c|c|c|c|c|}
\hline $\begin{array}{c}\text { S.No } \\
\cdot\end{array}$ & $\begin{array}{c}\text { Reachabilit } \\
\text { y set }\end{array}$ & $\begin{array}{c}\text { Anteceden } \\
\text { t set }\end{array}$ & $\begin{array}{c}\text { Intersectio } \\
\text { n set }\end{array}$ & $\begin{array}{c}\text { Iteration } \\
\text { / Levels }\end{array}$ \\
\hline 8. & 6 & 6,9 & 6 & \multirow{2}{*}{ VI } \\
\hline 9. & $\mathbf{1}$ & $1,4,6,9$ & $\mathbf{1}$ & \multirow{2}{*}{ VI } \\
\hline 10. & 4 & 4,9 & 9 & \\
\hline 12. & $1,4,6,9$ & 9 & 4 & \\
\hline 13. & 4 & 4 & 6 & \\
\hline 14. & $1,4,6$ & 6 & 6 & \\
\hline 15. & $1,4,6$ & 6 & \multicolumn{2}{|c|}{} \\
\hline
\end{tabular}

Table 11. Iteration VII

\begin{tabular}{|c|c|c|c|c|}
\hline $\begin{array}{c}\text { S.No } \\
\cdot\end{array}$ & $\begin{array}{c}\text { Reachabilit } \\
\mathbf{y} \text { set }\end{array}$ & $\begin{array}{c}\text { Anteceden } \\
\text { t set }\end{array}$ & $\begin{array}{c}\text { Intersectio } \\
\text { n set }\end{array}$ & $\begin{array}{c}\text { Iteration } \\
\text { / Levels }\end{array}$ \\
\hline 8. & $\mathbf{6}$ & 6,9 & $\mathbf{6}$ & \\
\cline { 1 - 4 } 10. & $\mathbf{4}$ & 4,9 & $\mathbf{4}$ & \multirow{2}{*}{ VII } \\
\hline 12. & $4,6,9$ & 9 & 9 & \\
\hline 13. & 4 & 4 & 4 & \\
\hline 14. & 4,6 & 6 & 6 & \\
\hline 15. & 4,6 & 6 & 6 & \\
\hline
\end{tabular}

Table 12. Iteration VIII

\begin{tabular}{|c|c|c|c|c|}
\hline S.No. & $\begin{array}{c}\text { Reachabi } \\
\text { lity set }\end{array}$ & $\begin{array}{c}\text { Antecedent } \\
\text { set }\end{array}$ & $\begin{array}{c}\text { Intersectio } \\
\text { n set }\end{array}$ & $\begin{array}{c}\text { Iteration/ } \\
\text { Levels }\end{array}$ \\
\hline 12. & $\mathbf{9}$ & $\mathbf{9}$ & $\mathbf{9}$ & VIII \\
\hline
\end{tabular}

\subsection{Classification of factors}

The critical success factors described earlier are classified in to four clusters viz. autonomous factor, dependent factors, linkage factors and independent factors (mentioned in Table 13 below). As it can be seen that there is no autonomous criteria . Criteria USG , LK, RGE and IC are drivers . Criteria such as LS and TLI are linkage criteria whereas IIP, LD, LSP and RC are dependent criteria.

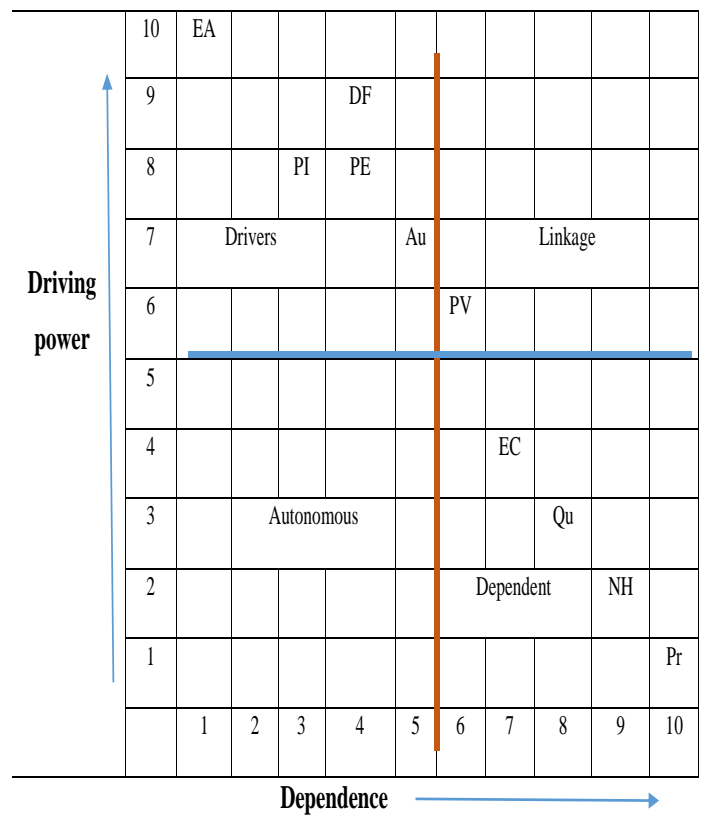

Table 13 . Driving Power \& Dominance Diagram

\subsection{ISM The Diagraph}

The diagraph presenting the hierarchy of the various barriers is shown in figure below.

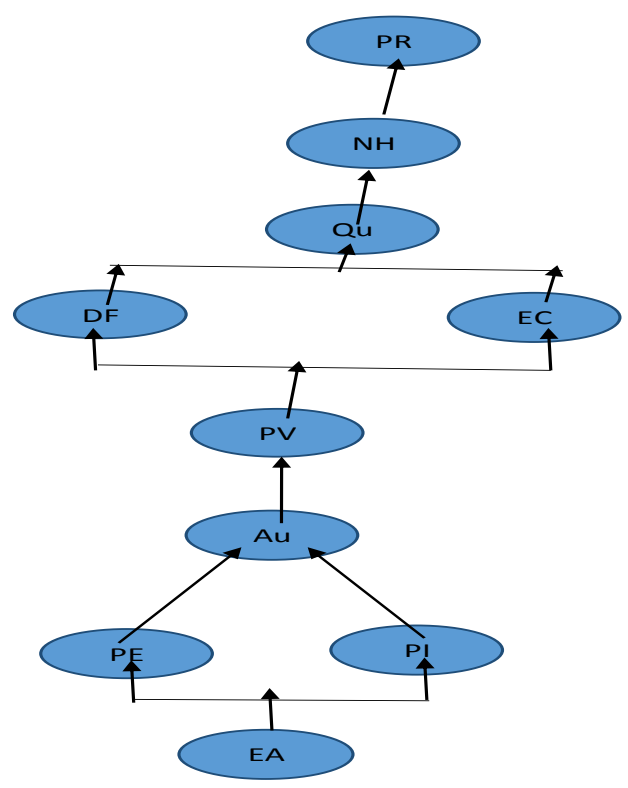

Figure 1: ISM Model

\section{CONCLUSIONS}

Present research work focuses on suggesting an ISM methodology for studying the interrelationship between various criteria affecting the consumer perception and ultimate purchase of organic food products. This topic is quite new and emerging from Indian perspective as consumers are getting environment conscious. The research topic can further be extended to include hybrid methodologies such as fuzzy DEMATEL or TOPSIS. 


\section{ACKNOWLEDGEMENTS}

Co-Author Remica Aggarwal is thankful to Prof. S.P Singh of IIT Delhi, India in disseminating the knowledge about ISM methodology which helped her substantially in preparing the manuscript.

\section{REFERENCES}

[1] Bahri-Ammari, N., Sandhir, S. and Dakhli, A. 2015. Perception and motivation to purchase organic products in Mediterranean countries: An empirical study in Tunisian context. Journal of Research in Marketing and Entrepreneurship. 17(1), 67-90 . [1]

[2] Hosseinpour, M., Mohamed, Z., Rezai, G., Shamsudin, M. N. \& Abdlatif, I. 2015. How Go Green Campaign Effects on Malaysia Intention towards Green Behaviour. Journal of Applied Sciences. 15(6), .929-933. [2]

[3] Gracia, A. and Magistris, T. de. 2007. Organic food product purchase behaviour: a pilot study for urban consumers in the South of Italy. Spanish Journal of Agricultural Research, 5(4), 439-451.[3]

[4] Mc Eachern, M. and Mc Clean, P. 2002. Organic purchasing motivations and attitudes: Are they ethical?. International Journal of Consumer Studies. 26, 85-92. [4]

[5] Harper, G. C. and Makatouni, A. 2002. Consumer perception of organic food production and farm animal welfare. British Food Journal, 104(3/4/5), 287-299. https://doi.org/10.1108/00070700210425723.

[6] Makatouni, A. 2002. What motivates consumers to buy organic food in the UK?. British Food Journal. 104, 345-352.

[7] Chen, M. F. 2007. Consumers attitudes and purchase intentions in relation to organic foods in Taiwan: Moderating effects of food-related personality traits. Food Quality and Preference, 18, 1008-1021.

[8] Roitner-Schobesberger, B., Darnhofer, I., Somsook, S. and Vogl, C. R. 2008. Consumer perception of organic foods in Bangkok, Thailand. Food Policy. 33, 112-121.

[9] Salleh, M. M., Ali, S. M., Harun, E. H., Jalil, M. A., \& Shaharudin, M. R. 2010. Consumer's perception and purchase intentions towards organic food products: Exploring attitude among academicians. Canadian Social Science. 6(6), 119-129.

[10] Stolz, H., Stolze, M., Hamm, U., Janssen, M. and Ruto, E. 2010. Consumer attitudes towards organic versus conventional food with specific quality attributes. NJASWageningen Journal of Life Sciences. 58, 67-72.

[11] Grankvist, G. and Biel, A. 2001. The importance of beliefs and purchase criteria in the choice of eco-labeled food products. Journal of Environmental Psychology, $21,405-410$.

[12] Urban , J. , Zverinoya , I. and Scansy , M. 2012. What motivates Czech consumers to buy organic food? , effects of label information on consumer willingness to pay for food attributes. Sociologický Časopis / Czech Sociological Review. 48(3), 509-536.

[13] Ghorbani, M. and Hamraz, S. 2009. A study on factors affecting on consumer's potential willingness to pay for organic products in Iran (a case study). Trends in Agriculture Economics. 2, 10-16.
[14] Napolitano, F., Braghieri, A., Piasentier, E., Favotto, S., Naspetti, S. and Zanoli, R. 2010. Effect of information about organic production on beef liking and consumer willingness to pay. Food Quality and Preference. 21, 207-212.

[15] Giovanni, P., Alessandro, M. P. and GianluigiI, G. 2012. Determinants of Regular and Occasional Consumers Intentions to Buy Organic Food. Journal of consumer affairs. 46(1), 157-169, Wiley.

[16] Linder, N. S., Uhl, G., Fliessbach, K., Trautner, P., Elger, C. E. and Weber, B. 2010. Organic labeling influences food valuation and choice. Neuro Image, 53, 215-220.

[17] Sakagami, M., Sato, M. and Ueta, K. 2006. Measuring consumer preferences regarding organic labeling and the JAS label in particular. New Zealand Journal of Agricultural Research. 49, 247-254.

[18] Zhifeng , G. and Schroeder, T.C. 2009. Effects of label information on consumer willingness-to-pay for food attributes. American Journal of Agricultural Economics. 91, 795- 809

[19] Schifferstien, H. N. J. and Oude Ophuis, P. A. M. 1998 Health-related determinants of organic food consumption in the Netherlands. Food Quality and Preference. 9, 119-133.

[20] Snyder, C. and Spaner, D. 2010. The Sustainability of Organic Grain Production on the Canadian Prairies. A Review. Sustainability. 2, 1016-1034.

[21] William, P. R. D. and Hammit, J. K. 2001. Perceived risks of conventional and organic produce: Pesticides, pathogens, and natural toxins. Risk Analysis. 21, 319 330.

[22] Mergenthaler, M., Weinberger, K. and Qaim, M. 2009. Consumer Valuation of Food Quality and Food Safety Attributes in Vietnam. Review of Agricultural Economics, 31(2), 266-283.

[23] Mishra, R. and Kaushik, N. 2013. Consumer Insights for Organic food Market: A Delhi-NCR study. www.apeejay.edu/aimtc/journal/docs/volume8/Volume8 No2Article2.pdf

[24] Bo, S. W. 2009. Factor Influencing Consumers' Perceptions, Intention to Purchase and Realised Purchase Behaviour for Organic Food in South Korea. (Doctorate Dissertation, University of Surrey)

[25] Verbeke, W. and Vackier, I. 2005. Individual determinants of fish consumption: application of the theory of planned behavior. Appetite.44, 67-82.

[26] Schwartz, S. H. 1992. Universals in the Content and Structure of Values: Theoretical Advances and Empirical Tests in 20 Countries. Advances in Experimental Social Psychology. 25, 1-65.

[27] Basha, M. B., Mason, C. and Shamsudin, M. F. 2015 Consumers Attitude Towards Organic Food. International Accounting and Business Conference. 31, 444-452.

[28] Mann, S. 2003. Why organic food in Germany is a merit good?. Food Policy. 28, 459-469.

[29] Bartels, J. and Rienders, M. 2010. Social identification, social representations, and consumer innovativeness in 
an organic food context: A cross-national comparison. Food Quality and Preference. 21, 347-352.

[30] Brown, C. and Sperow, M. 2005. Examining the cost of an all-organic diet. Journal of Food Distribution Research. 36, 20-26.

[31] Duffort, M. M. 2006. Minimising the impact? The meanings of organic food .http://www.atmq77.dsl.pipex.com/

[32] Pieniak, Z., Aertsen, J. and Verbeke, W. 2010. Subjective and objective knowledge as determinants of organic vegetable consumption. Food Quality and
Preference. 21,. 581-588.

[33] Warfield, J., N. 1974. Developing interconnection matrices in structural modeling', in the proceedings of IEEE Transactions on System, Man, and Cybernetics, SMC.4 (1), 81-87.

[34] Banerjee, R. Aggarwal , R. and Aggarwal , V. 2019.Perception Analysis of Consumers towards the usage of Sustainable Organic Food Products in Indian subcontinent.http://www.ijcaonline.org/archives/volume 178/number14/30602-2019918915.

ISBN : 973-9380900-07-6. 